\title{
Dual Archive Record System (DARS) for Increasing Evidence from School Accountability
}

\author{
Nina Oktarina, Joko Widodo, M. Murwatiningsih, S. Sriyanto
}

\begin{abstract}
The objective of the study was to develop a Dual Archive Record System (DARS) for increasing evidence from school accountability. Now, archive management in private schools at Indonesia was not effective because the archive process only uses a manual system or technology system. The impact of using this system is not accurate for supporting physical and legal evidence. Therefore, Dual Archive Record System (DARS) was developed to overcome these problems. The research approach uses research and development $(R \& D)$. The subject of this study is all of the private high school in Indonesia. The data were collected through observation, interview, documentation, and questionnaire. Then; the data were analyzed quantitatively; it was using a t-test on the paired data to know the difference of the actual and the new model. Besides that, analysis of data also uses qualitative approach through the data triangulation. The results showed that dual archive record system (DARS) can increase evidence of school accountability. Therefore; it was suggested for school to implement DAR for increasing evidence from school accountability because DARS has a significant contribution to evidence from school accountability.
\end{abstract}

Index Terms: Dual Archive Record System (DARS), Archive Management, Evidence, School Accountability.

\section{INTRODUCTION}

One of the most important thing as evidence from school accountability is the school archive. According to Alabi (2017), the school archive can be defined as information keeping documents on school administration. Similar to Burcak (2013), as a very important function for school, the archive is also strategically important that archivists believe in archive management has an impact on administrative education. It means that an archive should be managed well.

School archive management is the administrative responsibility of both principals and teachers to embrace ideal administrative practices that ensure effective and efficient school archive keeping in the school system (Ogbonnaya (1994) in a thesis by Dorcas, 2013). If the school has good management of archive, the information can be accessed easily so it helps school for giving evidence in school accountability. Accountability of school is one of the aspects that can measure school quality. The research result of Rosemarie (2013) regarding the accountability of

Revised Manuscript Received on September 22, 2019.

Nina Oktarina, Faculty of Economics, Universitas Negeri Semarang, Semarang, Indonesia.

Joko Widodo, Faculty of Economics, Universitas Negeri Semarang, Semarang, Indonesia.

M. Murwatiningsih, Faculty of Economics, Universitas Negeri Semarang, Semarang, Indonesia.

S. Sriyanto, Corresponden Author, Faculty of Teacher Training and Education, Universitas Muhammadiyah Purwokerto, Purwokerto, Indonesia. an effort to improve the quality of education. So, it will be realized if the school has document support.

In the line with Hanushek \& Raymond (2004) said that "The use of school accountability in the United States to improve student performance began in the separate states during the 1980s and was elevated through the federal No Child Left behind Act of 2001. Evaluating the impact of accountability is dif. cult because it applies to entire states and can be confused with other changes in the states. We consider how the differential introduction of accountability across states affects growth in student performance on the National Assessment of Educational Progress (NAEP). Our preliminary analysis and that: (1) accountability improves scores of all students; (2) there is no significant difference between simply reporting scores and attaching consequences; and, (3) while accountability tends to narrow the Hispanic-White gap, it tends to widen the Black-White gap in scores The last ding suggests that a single policy instrument cannot be expected to satisfy multiple simultaneous goals."

But, in fact, school accountability in Indonesia was still not optimal. Many private of high schools were not accountable (Jalal, 2011) because schools have not document support to be evidence. Research from Albert (2001) shows that good of archive handling in government organizations will enhance accountability. In line with Albert, research results of Lyons (2004) also showed that school accountability with the Commonwealth Accountability Testing System (CATS) used in the public schools in Kentucky suggests that school accountability is still low.

The same research from Rosemarie (2013) also showed that the accountability of schools in Indonesia is still low. It means that the quality of the school in Indonesia is poor. It was caused by the inability in providing evidence to internal and external parties. Oktarina (2016) indicates the poor quality of education causes that school archive management still the low capacity of a document to support school accountability. Whereas, an organization without archives, it cannot accountability (Ibara, 2010). Because, the effective of archive management at institution provide the information required for the proper functioning of organizations, including schools (Kemoni and Wamukoya, 2000).

In addition, many private high schools in Indonesia only use one type of archive management. Some schools use the manual system for archive management, and most of the schools use technology system. The impact of using a 
manual system was discovering an archive that difficult and also archive lost easily. Moreover, if schools have natural disasters or activity for renovation their building, the archive should move to other building, the archive will be lost, both in information and physical evidence. Meanwhile, the impact of using technology system for archive management is the archive remains questionable legality.

In detail, the condition of school archive management at private High School in Indonesia with a sampling of Java can be seen in table 1 .

Table 01. The Condition of Private High School Archive Management

\begin{tabular}{|c|c|c|}
\hline Regency/City & 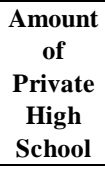 & $\begin{array}{c}\text { The Condition of } \\
\text { Archives Management }\end{array}$ \\
\hline Banjarnegara & 17 & 5 (bad), 12 (enough) \\
\hline Banyumas & 29 & 10 (bad), 19 (enough) \\
\hline Batang & 16 & 6 (bad), 10 (enough) \\
\hline Blora & 21 & 5 (bad), 16 (enough) \\
\hline Boyolali & 27 & 6 (bad), 21 (enough) \\
\hline Brebes & 39 & 10 (bad), 29 (enough) \\
\hline Cilacap & 46 & 15 (bad), 31 (enough) \\
\hline Demak & 73 & 13 (bad), 60 (enough) \\
\hline Grobogan & 57 & 5 (bad), 52 (enough) \\
\hline Jepara & 55 & 5 (bad), 50 (enough) \\
\hline Karanganyar & 8 & 5 (bad), 3 (enough) \\
\hline Kebumen & 33 & 13 (bad), 20 (enough) \\
\hline Kendal & 27 & 5 (bad), 22 (enough) \\
\hline Klaten & 16 & 5 (bad), 11 (enough) \\
\hline Kudus & 39 & 5 (bad), 12 (enough) \\
\hline Magelang & 39 & 9 (bad), 30 (enough) \\
\hline Pati & 73 & 20 (bad), 53 (enough) \\
\hline Pekalongan & 14 & 5 (bad), 9 (enough) \\
\hline Pemalang & 19 & 9 (bad), 10 (enough) \\
\hline Purbalingga & 8 & 5 (bad), 3 (enough) \\
\hline Purworejo & 18 & 5 (bad), 13 (enough) \\
\hline Rembang & 7 & 5 (bad), 2 (enough) \\
\hline Semarang & 22 & 3 (bad), 19 (enough) \\
\hline Sragen & 17 & 4 (bad), 13 (enough) \\
\hline Sukoharjo & 18 & 7 (bad), 11 (enough) \\
\hline Tegal & 28 & 5 (bad), 23 (enough) \\
\hline Temanggung & 10 & 5 (bad), 5 (enough) \\
\hline Wonogiri & 15 & 5 (bad), 10 (enough) \\
\hline Wonosobo & 10 & 7 (bad), 3 (enough) \\
\hline Kota Magelang & 8 & 1 (bad), 7 (enough) \\
\hline $\begin{array}{c}\text { Kota } \\
\text { Pekalongan }\end{array}$ & 11 & 2 (bad), 9 (enough) \\
\hline Kota Salatiga & 7 & 1 (bad), 6 (enough) \\
\hline Kota Semarang & 85 & 15 (bad), 70 (enough) \\
\hline Kota Surakarta & 41 & 5 (bad), 36 (enough) \\
\hline Kota Tegal & 8 & 2 (bad), 6 (enough) \\
\hline Amount & 961 & \\
\hline
\end{tabular}

Data source: Oktarina's Research (2016)

Therefore, Dual Archive Record System (DARS) was developed to overcome these problems. Dual Archive Record System (DARS) is a solution for the management of the school archive to be efficient and more systematic. DARS described archive management that uses technology from two different sources, namely electronic sources and printable paper sources that can be accessed at close range or distance (Borgman in Saputro, 2008). Meanwhile, according to Pendit (2007) explains that DAR is a continuum between conventional archives and digital archives, where the information presented in electronic and conventional media is used simultaneously.

DARS in this study is integration between the archive management in traditional and digital/electronic that are integrated through electronic network access and connected through the internet network or local computer network, but archives are also keeping by the manual system. The purposes DARS is able to overcome and complete the manual and technology system. So, every school should implement DARS to manage their school archive in order to support the document as evidence for school accountability.

\section{METHODS}

This research was using an R\&D (Research and Development) approach. R\&D based the principles and measures of Borg and Gall (1989) that has measured into four stages: (1) the stage of preliminary study, (2) the stage of development of the model, (3) the validation phase and a limited test to find the final hypothetical model, and (4) the stage of determination of the model is to find a model end and dissemination models.

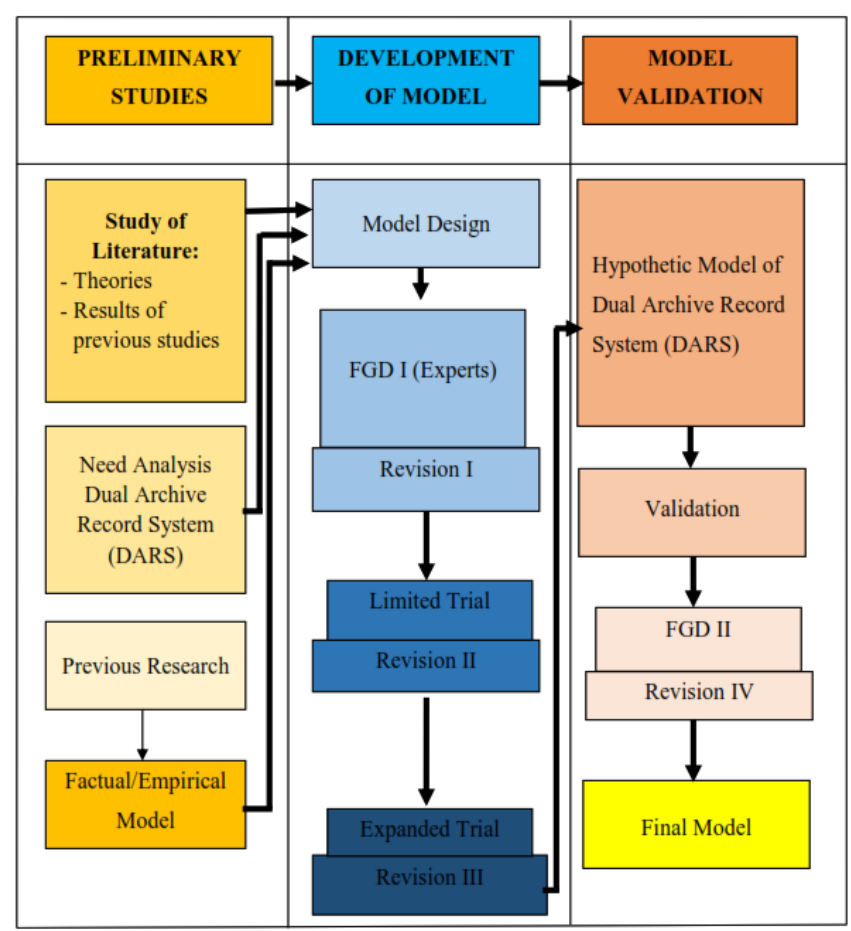

Figure 01 . The procedure of R\&D Model

Stage of preliminary studies carried out in the Widya Wiyata High School, Pancasila High School, Al Uswah High School, and Nurul Islam High School. Stage of design development models is developing of Dual Archive Record System for increasing evidence form school accountability with experts through focus group discussions and consultation/discussions. 
Validation phase and limited testing will be conducted on the object of research and validation internally with peers and experts people. The third phase will be implemented in the first year, the second year implementing external validation phase with the implementation of the model to find the final model and dissemination.

The data source can be divided into two, namely: (1) human; and (2) are not human. Source of human data is a subject or key informants. While the data sources from not human are sourced from documents. Determination of informants as a data source using purposive sampling techniques or with particular consideration is to know and be involved in the organization of schools, especially related to school accountability to both internal and external parties. Data sources include (1) headmaster, (2) teachers, (3) students, (4) administration staff, (5) parents, (6) stakeholders. Sources and techniques of data collection and research subjects can be seen in Table 2.

Figure 01. The Sources and Techniques of Data

Collection

\begin{tabular}{|c|c|c|}
\hline Research Goal & $\begin{array}{c}\text { The sources of } \\
\text { data }\end{array}$ & $\begin{array}{c}\text { The techniques } \\
\text { of data } \\
\text { collection }\end{array}$ \\
\hline $\begin{array}{c}\text { Describing the } \\
\text { implementation of } \\
\text { DARS }\end{array}$ & $\begin{array}{c}\text { Headmaster } \\
\text { Teachers } \\
\text { Students } \\
\text { Parents } \\
\text { Administration } \\
\text { Staff } \\
\text { Committee }\end{array}$ & $\begin{array}{c}\text { Observation } \\
\text { Interview } \\
\text { Document }\end{array}$ \\
\hline $\begin{array}{l}\text { Establishment of } \\
\text { Dual Archive Record } \\
\text { System for } \\
\text { increasing evidence } \\
\text { form school } \\
\text { accountability }\end{array}$ & $\begin{array}{c}\text { Headmaster } \\
\text { Teachers } \\
\text { Students } \\
\text { Parents } \\
\text { Administration } \\
\text { Staff } \\
\text { Committee } \\
\text { Expert people }\end{array}$ & $\begin{array}{l}\text { Observation } \\
\text { Interview } \\
\text { Document } \\
\text { Questioner }\end{array}$ \\
\hline $\begin{array}{l}\text { Establishment of a } \\
\text { hypothetical model of } \\
\text { Dual Archive Record } \\
\text { System for increasing } \\
\text { evidence form school } \\
\text { accountability }\end{array}$ & $\begin{array}{l}\text { Expert people, } \\
\text { headmaster, } \\
\text { administration } \\
\text { staff, teachers. }\end{array}$ & $\begin{array}{c}\text { Focus Group } \\
\text { Discussion }\end{array}$ \\
\hline
\end{tabular}

Data analysis process starts with examining all available data from various sources, namely from interviews, observation, documents, photos, images, and so forth. In this study using data analysis for the field is when the field data collection is ongoing, according to Milles and Huberman in Sugiyono (2012) through activities that reduction of data, display data, and conclusion.

In the qualitative approach, the data were analyzed using an interactive model that is through the process of data collection and presentation of data. At the time of the data presented cannot be concluded or irregularities are found, the data is reduced through verification. Data reduction is done continuously during the data collection takes place. Since the data analysis and verification is done, then at that time the researchers also began to make sense and interpret the data obtained. The researcher's decision gave meaning is to draw conclusions while still allowing it to be fixed. While the clear conclusion yet again reduced through verification. Then after researchers believe that the conclusion has been strong, the researchers interpret the results to interpret these meanings in the form of the conclusions. The first analysis is to explore the model and find the hypothetical model.

\section{RESULTS AND DISCUSSION}

If private high school is accountable, it means that school has good quality, so their output can be accepted by the public because of schools accountability depends on the quality of output. In the case, Indonesia has many private high schools that have not been accountable. It causes that school is not completing in giving evidence for school accountability. One of the evidence for school accountability is an archive. The archive is as an encyclopedia of school activities, so all of the archives should be kept. It is caused that the archive is useful to provide information to stakeholders.

According to Philip (2014), the effect of archive management that poor is decreasing in the efficiency of the school and operating cost. Besides, that school can be responsible for all of the activities that had done, because a school has no evidence to prove. In order to school can be mentioned accountable, a school must have effective of archive management. Archive management is systematic controlling of school for vital documents and archives. In essence, archive management was the foundation for high school to provide services and evidence for school accountability. Seniwoliba (2017) stated that no school can survive without archive management of its activities.

Based on the result of observation, school accountability in private high school was not complete and accurate, it caused that school cannot provide a document as evidence to support school accountability. In addition, some schools used one type of archive management. There was using manual and technologies system for managing their archive. Every school that uses a traditional system cannot find archive easily. The other impact of the traditional system for archive management was losing the archive when there is building renovation or natural disaster. While schools that use archive management based technology cannot prove the legality of an archive.

Under these conditions, the model developed with Dual Archive Record System (DARS) for increasing evidence from school accountability. The model image can be seen in Figure 02. 


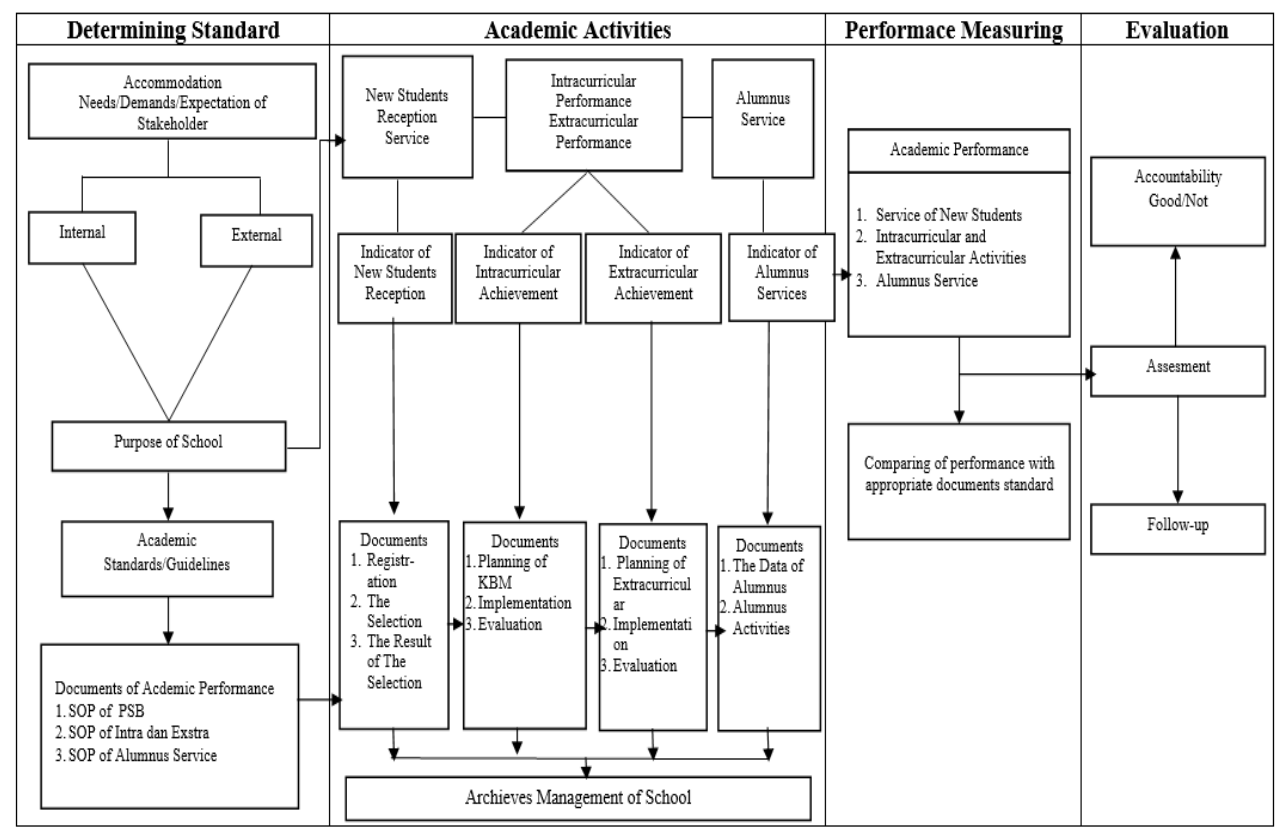

Figure 02. Dual Archive Record System Model for increasing Evidence from School Accountability

School archives management based Dual Archive Record System (DARS) model starts from the stage of archive identification. Archives identification was the activity for identifying archives according to the type. The archive will be collected by the authentic archives group. The archives that created will change in the form of electronic through the scanning process. After that, the electronic archives are managed through using dual archive record system (DARS). Process of archive management by DARS is a combination and integration of manual archive management with technology/electronic archive management.

The procedure of traditional system should choose and use a valid filing system. The choice of filing system was an important aspect in archive management, thus archive management can be running effectively and efficiently. The procedure of technology or electronic system for archive management was used to back up all of the document as evidence for supporting accountability school. Therefore, school archive management based dual archive record system (DARS) can increase evidence for school accountability. Through using DARS, a school can provide the evidence of document for supporting accreditation quickly, precise, and valid. Based on the result of the study, it can be suggested that private high school should implement or apply the archive management based DARS. It will be a significant contribution to increasing evidence from school accountability.

The development of school archive management based Dual Archive Record System (DARS) aims to overcome weaknesses in the manual archive management model is organized by the school. It also overcomes the weaknesses of using the archive management model based E-Archive. So far, schools only use one of the archive management model, which is a manual model or E-Archive model. The advantages of the archive management model based Dual Archive Record System are: (1) speeding up in searching of archive; (2) the information related to archive through E-Archive can be supported by documents which accurately; (3) ensuring security of archives, that is the loss of the archives due to natural disasters such as fires, floods, earthquakes; (4) providing authentic documents support that is legal; (5) providing easy of archive management; (6) giving easy for deletion archives; and (7) being backup of archive.

Implementation of an archive management model based Dual Archive Record System (DARS) has an advantage in speed of the archive tracks. Using the manual system still takes at least 1 minute for the rediscovery of an archive, while with DARS, the time to discovery of archive requires only 30 seconds. The hallmarks of DARS, in addition, speed in the rediscovery of the archive; it is also information that related to the archive is supported by accurate documents. Implementation of an archive management model based Dual Archive Record System (DARS) is able to provide supporting documents in the form of hard and soft files relating to information required by the school. It also guarantees the security of archives from natural disasters such as floods, fires, and earthquakes that could result in the loss or destruction of the archive manually. The disaster occurred when the school still has a backup of archives that exist in E-Archive system.

Model of archive management based Dual Archive Record System (DARS) also gives legal force in the jurisdictions with the authentic documents in the form of hard file other than the soft file. It also makes easy to archive management based on archive storage systems

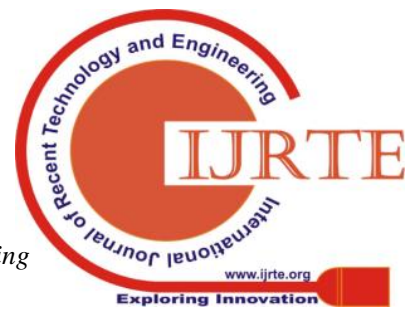


that have been determined by the school. The use of archive management model based Dual Archive Record System (DARS) also makes easy to archivist to specify the deletion and depreciation of archive.

\section{CONCLUSION}

The results showed that implementation Dual Archive Record System (DARS) can increase evidence from school accountability, in the case of private high school in Indonesia. Therefore, the suggestion in this study is every school is able to implement DARS to increase their quality of education through proving accurate, complete, authentic, and valid documents for school accountability.

\section{ACKNOWLEDGMENTS}

The author wishes to thank for all of the informants in this research, Widya Wiyata High School, Pancasila High School, Al Uswah High School, and Nurul Islam High School for providing information in the conduct of this study and also for their helpful remarks on earlier versions of this article.

\section{REFERENCES}

1. Alabi, Amos Oyetunde. 2017. Records Keeping for Effective Administration of Secondary Schools. Journal of Public Administration and Governance. Volume 7. Page 66-74. http://jpag.macrothink.org

2. Albert, Meijer. 2001. Accountability in an Information Age: Opportunities and Risks for Records Management. Netherland: Kluwer Academic Publisher.

3. Borg, R Walter \& Gall, Meredith D. 1989. Educational Research an Introduction Fifth Edition. New York: Longman.

4. Burcak Senturk. 2013. The Use of Archives in Education: Examples From Abroad. International on New Trends in Education and Their Implication. Volume 4. Page 108-114.

5. Dorcas, Omaha Fatu. 2013. Management of School Records in Secondary Schools in Otukpo Education Zone. Thesis. Nsukka: University of Nigeria.

6. Hanushek and Raymond. 2004. The Effect of School Accountability Systems on The Level and Distribution of Student Achievement. Journal of the European Economic Association, 2 (2): 406 - 415.

7. Ibara, E.C. (2010). Perspectives in Educational Administration. Port Harcourt, Nigeria: Rodi Printing and Publishing

8. Kemoni H., Wamukoya J. 2000. Preparing for the management of electronic records at Moi Kenned Jay \& Cherryl Schauder (1998). Records Management: A Guide to Corporate Record Keeping. Melbourne: Longman.

9. Jalal, F. (2011). Indonesian Paradigm. Jakarta, Gramedia.

10. Lyons, Robert. 2004. The Influence of Socioeconomic Factors on Kentucky's Public School Accountability System: Does Poverty Impact School Effectiveness? EPPA Journal, 12 (37) : 1-32.

11. Philip Usman Akor and Julie Udensi. 2014. An Assessment of Record Mangement System in Establishment Division of Two Universities in Nigeria. International Letters of Social and Humanistic Sciences. Volume 13. Page 97-109. https://doi:10.10852/www.scipress.com/ILSHS.13.97

12. Oktarina, N. (2016). Archive Management in Private High School in Central Java. Semarang, Universitas Negeri Semarang.

13. Oktarina, N, \& Pramusinto, H. (2016). School Accountability based on E-Archives at High School in Semarang. International Journal of the Computer, the Internet and Management, 24-26.

14. Rosemarie (2013)."Accountability as an Effort to Improve Education Quality." Journal of Economics and Business 2(14).

15. Seniwoliba, A.J., Mahma, A.V., and Abilla, B.J. 2017. Challenges of records management in higher education in Ghana: The case of University for Development Studies. International Journal of Educational Policy Research and Review. Volume 4. Page 29-41. https://doi.org/10.15739/IJEPRR.17.005

16. Sugiyono. 2012. Qualitative, Quantitative, and R\&D Research. Bandung Alfabeta.

\section{AUTHORS PROFILE}

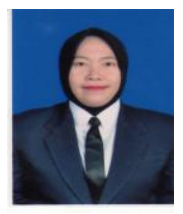

Nina Oktarina is an associate professor at Faculty of Economics, Universitas Negeri Semarang. She is a doctor in the field of Education management. Her research is related to education management, education administration, school records management, school accountability, human resources in education, office management and entrepreneurship. Publications in international conference and journals related to the topic. She is also active in the Association of Indonesian Lecturers and Experts (ADRI) and the Association of Indonesian Office Administration Education (ASPAPI). Community service activities that have been carried out are related to the management of archives in schools, the development of learning models, entrepreneurship, and the use of IT in records management.

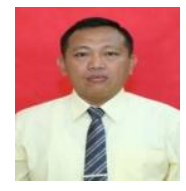

Joko Widodo is a Professor at Faculty of Economics, Universitas Negeri Semarang. $\mathrm{He}$ is a Professor in management. His research related to education management, education administration, school accountability, education funding, and entrepreneurship. Publications in international conference and journals related to the topic. Community service activities that have been carried out are related to the development of learning models, entrepreneurship, and school accountability. In addition, he was also a guest speaker in conference and workshop about Education

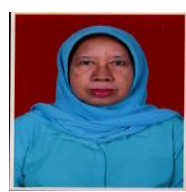

Murwatiningsih is an associate professor at Faculty of Economics, Universitas Negeri Semarang. She is a doctor in the field of management. Her research related with management, education marketing management, entrepreneurship, and Total Quality management (TQM). Publications in international conference and journals related to the topic. The community service activities that have been carried out are related to TQM, entrepreneurship, and the quality of Education services.

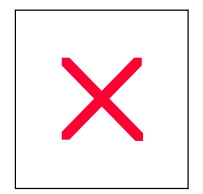

S. Sriyanto, Corresponden Author. He is a doctor in the field of social studies at Faculty of Teacher Training and Education, Universitas Muhammadiyah Purwokerto. His research related with assertiveness, social skills, and education. Publications in international conference and journals related to the topic. 